\title{
Review Article \\ Review and Phylogenetic Evaluation of Associations between Microdontinae (Diptera: Syrphidae) and Ants (Hymenoptera: Formicidae)
}

\author{
Menno Reemer \\ Naturalis Biodiversity Center, European Invertebrate Survey, P.O. Box 9517, 2300 RA Leiden, The Netherlands \\ Correspondence should be addressed to Menno Reemer; menno.reemer@naturalis.nl
}

Received 11 February 2013; Accepted 21 March 2013

Academic Editor: Jean-Paul Lachaud

Copyright (C) 2013 Menno Reemer. This is an open access article distributed under the Creative Commons Attribution License, which permits unrestricted use, distribution, and reproduction in any medium, provided the original work is properly cited.

\begin{abstract}
The immature stages of hoverflies of the subfamily Microdontinae (Diptera: Syrphidae) develop in ant nests, as predators of the ant brood. The present paper reviews published and unpublished records of associations of Microdontinae with ants, in order to discuss the following questions. (1) Are all Microdontinae associated with ants? (2) Are Microdontinae associated with all ants? (3) Are particular clades of Microdontinae associated with particular clades of ants? (4) Are Microdontinae associated with other insects? A total number of 109 associations between the groups are evaluated, relating to 43 species of Microdontinae belonging to 14 genera, and to at least 69 species of ants belonging to 24 genera and five subfamilies. The taxa of Microdontinae found in association with ants occur scattered throughout their phylogenetic tree. One of the supposedly most basal taxa (Mixogaster) is associated with ants, suggesting that associations with ants evolved early in the history of the subfamily and have remained a predominant feature of their lifestyle. Among ants, associations with Microdontinae are known from subfamilies Ponerinae, Dolichoderinae, Formicinae, Myrmicinae, and Pseudomyrmecinae. These subfamilies comprise more than $95 \%$ of all ant species. Interestingly, no associations are known with "dorylomorph" ants (army ants and relatives).
\end{abstract}

\section{Introduction}

Ants "run much of the terrestrial world," is the claim of Hölldobler and Wilson [1] in the opening lines of their landmark book The ants. This may be true, but the colonies of ants-on their turn-are to some extent affected by many species of myrmecophilous organisms which live in their nests, especially insects and other arthropods. Some of these are not detrimental to the ants or can even be considered beneficial, for example, because they clean up the nests or provide the ants with certain nutrients. Other species of myrmecophilous insects, however, are predators of the ant brood or the adult ants. The larvae of hoverflies of the subfamily Microdontinae (Diptera: Syrphidae) exemplify the latter category.

The nature of the feeding habits of the slug-like larvae of Microdontinae has long remained uncertain. Several authors have suggested that they live as scavengers or feed on pellets of food ejected by the worker ants [2-5]. More recently, however, accumulated evidence showed that larvae of at least a number of species of Microdon Meigen and Omegasyrphus Giglio-Tos are predators, feeding on eggs, larvae, and pupae of ants [610]. There are a few reports of Microdontinae larvae feeding on aphids and coccids attended by ants [11-13], but these could so far not be confirmed. Little is known about the degree of taxonomic specialization exhibited by Microdontinae with respect to their host ants, but available evidence suggests that Microdon species are highly specialized, although this may differ between species [14-17]. It seems probable that a certain degree of host specialization is required for predators living in ants nests, because the predators need to make sure that they are not recognized by the ants as hostile intruders. For some Microdon species it has been established that their larvae use "chemical mimicry" to prevent them from being attacked by the ants: the fly larvae possess cuticular hydrocarbons similar to those of the ants [14, 15].

The impact of larvae of Microdontinae on ant colonies is potentially large. Duffield [7] reported that third-instar Microdon larvae could consume 8-10 ant larvae in $30 \mathrm{~min}$ utes, and Barr [6] stated that a Microdon larva may consume 
up to 125 ant larvae during its life. With an average number of five or six Microdon larvae per nest [6], over 700 ant larvae would be consumed per nest. A more indirect way in which Microdon larvae possibly affect the fitness of ant colonies was revealed by Gardner et al. [18]. They found that workers of a Microdon-infested polygynous ant colony are less closely related to each other than workers of uninfested colonies. They explained this by arguing that it is harder for a Microdon larva to intrude in a genetically homogeneous colony, because in such a colony the worker ants smell more alike and will therefore more easily recognize an intruder. So, a decreased genetic diversity will reduce the chance of becoming infested with Microdon larvae.

Worldwide, 454 valid species of Microdontinae are known [19], which may be only half or less of the actual species number (estimation by the author based on unpublished data). Approximately 12,500 species of ants are known [20]. Little is known about associations between species of Microdontinae and species of ants. Because of the potential impact of these flies on ant colonies, and hence on ecosystems, it is interesting to learn more about these associations. Besides, this information may be useful for research on subjects like the evolution of host association, chemical mimicry, and (triggers of) cryptic speciation. The present paper aims to summarize available knowledge of associations of Microdontinae with ants, in order to answer the following questions.

(1) Are all Microdontinae associated with ants?

(2) Are Microdontinae associated with all ants?

(3) Are particular clades of Microdontinae associated with particular clades of ants?

(4) Are Microdontinae also associated with other insects besides ants?

\section{Material and Methods}

2.1. Host Associations. The literature has been reviewed and records on associations of Microdontinae with ants and other insects were assembled. Omitted from the dataset were references to host associations for which considerable doubt exists as to whether the identifications are correct. This is especially the case with several older references to European species, since it became clear that certain taxa actually comprise cryptic species complexes, as in Microdon analis (Macquart)/M. major Andries and M. mutabilis (Linnaeus)/M. myrmica (Schönrogge et al.) [16, 21]. The following records were excluded because of this reason (names as in cited publication): Microdon mutabilis in nests of Lasius niger (Linneaus), Myrmica ruginodis Nylander, and Formica fusca Linnaeus [2]; Microdon eggeri Mik in nests of Lasius niger [2]; Microdon eggeri in nests of Formica sanguinea Latreille [22]; Microdon devius (Linnaeus) in nests of Formica sanguinea and Lasius fuliginosus (Latreille) [23-25]; Microdon devius in nests of Formica fusca, and Formica rufa Linnaeus [25]; Microdon mutabilis in nests of Formica fusca, F. rufa, F. rufibarbis Fabricius, Lasius niger, L. brunneus (Latreille), and L. flavus (Fabricius) [25]. These records were, however, included in a more generalized way, that is, as associations of species of Microdon s.s. with the ant genera Formica Linnaeus, Lasius Fabricius, and Myrmica Latreille. The records reported in the literature on European Microdon (the only genus of Microdontinae occurring in Europe) have not been fully surveyed, as this would not add information to the generic level at which this study was conducted.

Weber [26] reported larvae "of the Microdon type" from nests of the ant Ectatomma ruidum (Roger) (subfamily Ectatomminae). However, his figure does not show a Microdon larva but a larva belonging to another family of Diptera Cyclorrhapha (possibly Phoridae). Hence, this record was excluded from the dataset analyzed in this paper.

In addition to the survey of the literature, associations found in entomological collections were recorded. Such records were noted when an empty puparium was mounted together with an adult specimen, and the label mentioned a genus or species of host ant. Records were taken fro the following collections: Natural History Museum, London (BMNH); National Museums of Scotland, Edinburgh (RSME); United States National Museum, Washington D.C. (USNM); Zoölogisch Museum Amsterdam (ZMAN, recently included in the collection of Naturalis Biodiversity Center (RMNH), Leiden).

2.2. Taxonomy and Phylogeny. Classification of Microdontinae follows Reemer and Ståhls [19]. Classification of ants is updated to modern standards according to Bolton [27]. A recent phylogenetic hypothesis for intrageneric relationships of Microdontinae is obtained from Reemer and Ståhls [28], who presented a tree based on parsimony analysis of combined molecular and morphological characters. All specific taxa were pruned from this tree in order to obtain a tree of generic relationships only. For ants, several recent phylogenetic hypotheses are available (e.g., $[29,30]$ ), which are incongruent at some points. Therefore, in the present study, the tree of extant subfamilies as compiled by Ward [31] is used, because this summarizes relationships which are well supported by all recent studies.

\section{Results}

Table 1 lists 109 recorded associations of Microdontinae with ants, 105 of which are based on the literature and four are based on collection surveys. These records concern 43 species of Microdontinae belonging to 14 genera, and at least 69 species of ants belonging to 24 genera and five subfamilies (Ponerinae, Dolichoderinae, Pseudomyrmecinae, Formicinae, and Myrmicinae). The distribution of recorded association over the major biogeographic regions is as follows: Nearctic 62, Palaearctic 18, Neotropical 18, Australia/Oceania 6, Afrotropical 4, and Oriental 1.

Figure 1 presents a phylogenetic hypothesis for 28 (out of 43) genera of Microdontinae, with indications of known associations with subfamilies of ants. Figure 2 presents a phylogenetic hypothesis for all extant subfamilies of ants, with indications of known associations with Microdontinae. 
TABLE 1: List of all known records of immature stages of Microdontinae found in association with ants. The records are first sorted by ant subfamily, then alphabetically by ant genus and species. Observation: 1: larva(e) or pupa(e) found in nest; 2: freshly emerged specimens found near nest; 3: adult female(s) observed ovipositing near nest entrance; 4: adult specimens observed near nest.

\begin{tabular}{|c|c|c|c|c|}
\hline Ant taxon & Microdontine taxon & Country/region & Source & Observation \\
\hline \multicolumn{5}{|l|}{ Ponerinae } \\
\hline Pachycondyla Smith & Hypselosyrphus spec. & Mexico & $\begin{array}{l}\text { G. Pérez-Lachaud and } \\
\text { J.-P. Lachaud, pers. } \\
\text { comm. }\end{array}$ & 1 \\
\hline \multicolumn{5}{|l|}{ Dolichoderinae } \\
\hline Azteca trigona Emery & Microdontinae spec. & British Guiana & {$[32]$} & 1 \\
\hline Azteca spec. & Ceratophya spec. & Costa Rica & $\begin{array}{c}\text { Leg. M. Zumbado, } \\
\text { G.E. Rotheray and G. } \\
\text { Hancock, collection: } \\
\text { RSME }\end{array}$ & 1 \\
\hline Dolichoderus diversus Emery & Microdontinae spec. & Panama & {$[32]$} & 1 \\
\hline Forelius pruinosus (Roger) & $\begin{array}{l}\text { Microdon (Dimeraspis) fuscipennis } \\
\text { (Macquart) }\end{array}$ & USA & {$[7]$} & 1 \\
\hline Iridomyrmex chasei Forel & Oligeriops dimorphon (Ferguson) & Australia & {$[33]$} & 1 \\
\hline Iridomyrmex rufoniger (Lowne) & Oligeriops iridomyrmex (Shannon) & Australia & {$[34]$} & 1 \\
\hline Linepithema humile (Mayr) & Mixogaster lanei Carrera and Lenko & Argentina & {$[35]$} & 1 \\
\hline Linepithema oblongum (Santschi) & Microdontinae spec. & Argentina & {$[36]$} & 1 \\
\hline Tapinoma sessile (Say) & $\begin{array}{l}\text { Microdon (Dimeraspis) globosus } \\
\text { (Fabricius) }\end{array}$ & USA & {$[37,38]$} & 1 \\
\hline Technomyrmex albipes (Smith) & Bardistopus papuanum Mann & Solomon Islands & [39] & 1 \\
\hline Technomyrmex fulvus (Wheeler) & Microdontinae spec. & Panama & {$[40]$} & 1 \\
\hline \multicolumn{5}{|l|}{ Pseudomyrmecinae } \\
\hline Pseudomyrmex ejectus (Smith) & $\begin{array}{l}\text { Rhopalosyrphus ramulorum Weems and } \\
\text { Deyrup }\end{array}$ & USA & {$[41]$} & 1 \\
\hline Pseudomyrmex gracilis (Fabricius) & Microdontinae spec. & Mexico & {$[42]$} & 1 \\
\hline Pseudomyrmex simplex (Smith) & $\begin{array}{l}\text { Rhopalosyrphus ramulorum Weems and } \\
\text { Deyrup }\end{array}$ & USA & {$[41]$} & 1 \\
\hline Tetraponera penzigi (Mayr) & Microdontinae spec. & East Africa & {$[9]$} & 1 \\
\hline \multicolumn{5}{|l|}{ Formicinae } \\
\hline Brachymyrmex coactus Mayr & Microdontinae spec. & Brazil & {$[43]$} & 1 \\
\hline Camponotus atriceps (Smith) & $\begin{array}{l}\text { Microdon (Chymophila) fulgens } \\
\text { Wiedemann }\end{array}$ & USA & {$[38]$} & \\
\hline Camponotus herculeanus (Linnaeus) & Microdon (s.s.) piperi Knab & USA & {$[8,38,44]$} & 1 \\
\hline Camponotus hildebrandti Forel & Microdontinae spec. & Madagascar & [25] & 1 \\
\hline Camponotus laevigatus (Smith) & Microdon (s.s.) piperi Knab & USA & {$[44]$} & 1 \\
\hline Camponotus modoc Wheeler & Microdon (s.s.) albicomatus Novak & USA & {$[44]$} & 1 \\
\hline Camponotus modoc Wheeler & Microdon (s.s.) piperi Knab & USA & {$[44,45]$} & 1 \\
\hline Camponotus mus Roger & Masarygus planifrons Brethes & Argentina & [46] & 3 \\
\hline Camponotus nitidior (Santschi) & Microdontinae spec. & Costa Rica & {$[47]$} & \\
\hline Camponotus novaeboracensis (Fitch) & Microdon (s.s.) cothurnatus Bigot & USA & {$[38]$} & 1 \\
\hline Camponotus novaeboracensis (Fitch) & Microdon (s.s.) tristis Loew & USA & {$[38]$} & 1 \\
\hline Camponotus novogranadensis Mayr & Microdontinae spec. & Panama & {$[32]$} & \\
\hline Camponotus obscuripes Mayr & $\begin{array}{l}\text { Microdon (s.s.) macrocerus Hironaga and } \\
\text { Maruyama }\end{array}$ & Japan & {$[48]$} & 2 \\
\hline Camponotus pennsylvanicus (DeGeer) & Microdon (s.s.) cothurnatus Bigot & USA & {$[38]$} & 1 \\
\hline Camponotus pennsylvanicus (DeGeer) & Microdon (s.s.) tristis Loew & USA & {$[37]$} & 1 \\
\hline Camponotus sp. cf. textor Forel & Microdontinae spec. & Mexico & [49] & \\
\hline Camponotus vicinus Mayr & Microdon (s.s.) piperi Knab & USA & {$[44,50]$} & 1 \\
\hline
\end{tabular}


TABle 1: Continued.

\begin{tabular}{|c|c|c|c|c|}
\hline Ant taxon & Microdontine taxon & Country/region & Source & Observation \\
\hline Camponotus ?vicinus Mayr & Microdon (s.s.) cothurnatus Bigot & USA & {$[50]$} & 1 \\
\hline Camponotus spec. & Microdon (s.s.) piperi Knab & USA & {$[38]$} & 1 \\
\hline Formica accreta Francoeur & Microdon (s.s.) albicomatus Novak & USA & {$[44]$} & 1 \\
\hline Formica accreta Francoeur & Microdon (s.s.) cothurnatus Bigot & USA & {$[44]$} & 1 \\
\hline Formica accreta Francoeur & Microdon (s.s.) piperi Knab & USA & {$[44]$} & 1 \\
\hline Formica adamsi whymperi Wheeler & Microdon (s.s.) cothurnatus Bigot & USA & {$[44]$} & 1 \\
\hline Formica adamsi whymperi Wheeler & Microdon (s.s.) piperi Knab & USA & {$[44]$} & 1 \\
\hline Formica argentea Wheeler & Microdon (s.s.) lanceolatus Adams & USA & {$[51]$} & 1 \\
\hline Formica aserva Forel & Microdon (s.s.) cf. tristis Loew & USA & {$[4]$} & 1 \\
\hline Formica aserva Forel & Microdon (s.s.) albicomatus Novak & USA & {$[44]$} & 1 \\
\hline Formica aserva Forel & Microdon (s.s.) cothurnatus Bigot & USA & {$[8,38,44]$} & 1 \\
\hline Formica aserva Forel & Microdon (s.s.) piperi Knab & USA & {$[44]$} & 1 \\
\hline Formica densiventris Viereck & Microdon (s.s.) manitobensis Curran & USA & {$[44]$} & 1 \\
\hline Formica difficilis Emery & Microdon (s.s.) cf. tristis Loew & USA & {$[4]$} & 1 \\
\hline Formica exsectoides Forel & Microdon (s.s.) abstrusus Thompson & USA & [38] & 1 \\
\hline Formica fusca Linnaeus & Microdon (s.s.) albicomatus Novak & USA & [38] & 1 \\
\hline Formica fusca Linnaeus & Microdon (s.s.) spec. & Europe & {$[25]$} & 1 \\
\hline Formica japonica Motschoulsky & $\begin{array}{l}\text { Microdon (s.s.) kidai Hironaga and } \\
\text { Maruyama }\end{array}$ & Japan & {$[48]$} & 2 \\
\hline Formica japonica Motschoulsky & $\begin{array}{l}\text { Microdon (s.s.) yokohamai Hironaga and } \\
\text { Maruyama }\end{array}$ & Japan & {$[48]$} & 2 \\
\hline Formica lemani Bondroit & $\begin{array}{l}\text { Microdon (s.s.) murayami Hironaga and } \\
\text { Maruyama }\end{array}$ & Japan & {$[48]$} & 4 \\
\hline Formica lemani Bondroit & Microdon (s.s.) mutabilis Linnaeus & United Kingdom & {$[16]$} & 1 \\
\hline Formica neoclara Emery & Microdon (s.s.) albicomatus Novak & USA & {$[44]$} & 1 \\
\hline Formica neoclara Emery & Microdon (s.s.) cothurnatus Bigot & USA & {$[44]$} & 1 \\
\hline Formica neoclara Emery & Microdon (s.s.) manitobensis Curran & USA & {$[44]$} & 1 \\
\hline Formica neoclara Emery & Microdon (s.s.) piperi Knab & USA & {$[44]$} & 1 \\
\hline Formica neogagates Viereck & Microdon (s.s.) lanceolatus Adams & USA & {$[44]$} & 1 \\
\hline Formica neorufibarbis Emery & Microdon (s.s.) albicomatus Novak & USA & {$[44]$} & 1 \\
\hline Formica neorufibarbis Emery & Microdon (s.s.) piperi Knab & USA & {$[44]$} & 1 \\
\hline Formica obscuripes Forel & Microdon (s.s.) albicomatus Novak & USA & {$[38]$} & 1 \\
\hline Formica obscuripes Forel & Microdon (s.s.) cothurnatus Bigot & USA & {$[44,51]$} & 1 \\
\hline Formica obscuripes Forel & Microdon (s.s.) piperi Knab & USA & {$[44]$} & 1 \\
\hline Formica obscuripes Forel & Microdon (s.s.) cf. tristis Loew & USA & [4] & 1 \\
\hline Formica obscuripes Forel & Microdon (s.s.) xanthopilis Townsend & USA & {$[44,52]$} & 1 \\
\hline Formica obscuriventris Mayr & Microdon (s.s.) cothurnatus Bigot & USA & {$[44]$} & 1 \\
\hline Formica obscuriventris Mayr & Microdon (s.s.) piperi Knab & USA & {$[44]$} & 1 \\
\hline Formica podzolica Francoeur & Microdon (s.s.) cothurnatus Bigot & USA & [44] & 1 \\
\hline Formica ravida Creighton & Microdon (s.s.) cothurnatus Bigot & USA & {$[44,53]$} & 1 \\
\hline Formica ravida Creighton & Microdon (s.s.) piperi Knab & USA & {$[44]$} & 1 \\
\hline Formica rufa Linnaeus & Microdon (s.s.) spec. & Europe & {$[25]$} & 1 \\
\hline Formica rufibarbis Fabricius & Microdon (s.s.) spec. & Europe & {$[25]$} & 1 \\
\hline Formica sanguinea Latreille & Microdon (s.s.) spec. & Europe & {$[22-25]$} & 1 \\
\hline Formica schaufussi Mayr & Microdon (s.s.) ocellaris Curran & USA & [38] & 1 \\
\hline Formica schaufussi Mayr & Microdon (s.s.) cf. tristis Loew & USA & {$[4]$} & 1 \\
\hline Formica subsericea Say & Microdon (s.s.) megalogaster Snow & USA & {$[38,54]$} & 1 \\
\hline Lasius alienus (Foerster) & Microdon (s.s.) ruficrus Williston & Canada & [38] & 1 \\
\hline
\end{tabular}


TABLE 1: Continued.

\begin{tabular}{|c|c|c|c|c|}
\hline Ant taxon & Microdontine taxon & Country/region & Source & Observation \\
\hline Lasius brunneus (Latreille) & Microdon (s.s.) spec. & Europe & {$[25]$} & 1 \\
\hline Lasius fuliginosus (Latreille) & Microdon (s.s.) spec. & Europe & [23-25] & 1 \\
\hline Lasius flavus (Fabricius) & Microdon (s.s.) spec. & Europe & {$[25]$} & 1 \\
\hline Lasius niger (Linnaeus) & Microdon (s.s.) ?mutabilis (Linnaeus) & France & {$[55]$} & 1 \\
\hline Lasius niger (Linnaeus) & Microdon (s.s.) spec. & Europe & {$[25]$} & 1 \\
\hline Lasius pallitarsis (Provancher) & Microdon spec. & USA & {$[56]$} & \\
\hline Lasius spec. & Microdon (s.s.) ruficrus Williston & USA & [38] & 1 \\
\hline Lepisiota capensis (Mayr) & Paramixogaster acantholepidis (Speiser) & South Africa & [57] & 1 \\
\hline $\begin{array}{l}\text { Polyergus lucidus Mayr } \\
\text { (slave: Formica schaufusi Mayr) }\end{array}$ & $\begin{array}{l}\text { Microdon (Chymophila) fulgens } \\
\text { Wiedemann }\end{array}$ & USA & {$[38]$} & 1 \\
\hline Polyrhachis lamellidens Smith & $\begin{array}{l}\text { Microdon (Chymophila) katsurai } \\
\text { Maruyama and Hironaga }\end{array}$ & Japan & {$[58]$} & 3 \\
\hline Polyrhachis spec. & Microdon (s.l.) waterhousei Ferguson & Australia & $\begin{array}{l}\text { Collection: USNM; } \\
\text { ant identified by J. } \\
\text { Doyen }\end{array}$ & 1 \\
\hline \multicolumn{5}{|l|}{ Myrmicinae } \\
\hline Acromyrmex coronatus (Fabricius) & Microdon (Chymophila) tigrinus Curran & Brazil & {$[59,60]$} & 1 \\
\hline Aphaenogaster fulva Roger & Omegasyrphus coarctatus (Loew) & USA & [37] & 1 \\
\hline Crematogaster brasiliensis Mayr & Microdontinae spec. & Costa Rica & {$[61]$} & 1 \\
\hline Crematogaster crinosa Mayr & Stipomorpha wheeleri (Mann) & Panama & {$[62]$} & 1 \\
\hline Crematogaster crinosa Mayr & Microdontinae spec. & Panama & {$[32]$} & 1 \\
\hline Crematogaster cf. crinosa Mayr & Microdontinae spec. & British Guiana & {$[32]$} & 1 \\
\hline Crematogaster limata Smith & Pseudomicrodon biluminiferus (Hull) & Brazil & [43] & 1 \\
\hline Crematogaster spec. & Paramixogaster crematogastri (Speiser) & South Africa & {$[57]$} & 1 \\
\hline Crematogaster spec. & Stipomorpha spec. Nov. & Brazil & $\begin{array}{c}\text { Collection: BMNH; } \\
\text { ant identified by O.W. } \\
\text { Richards }\end{array}$ & 1 \\
\hline Leptothorax spec. & Microdon (s.s.) mutabilis Linnaeus & United Kingdom & {$[16]$} & 1 \\
\hline Monomorium minimum (Buckley) & Omegasyrphus baliopterus (Loew) & USA & {$[10,63]$} & 1 \\
\hline Monomorium minimum (Buckley) & Omegasyrphus painteri (Hull) & USA & {$[38]$} & 1 \\
\hline Monomorium minimum (Buckley)* & Omegasyrphus coarctatus (Loew) & USA & {$[37,64]$} & 1 \\
\hline Myrmica incompleta Provancher & Microdon (s.s.) albicomatus Novak & USA & [15] & 1 \\
\hline Myrmica scabrinodis Nylander & $\begin{array}{l}\text { Microdon (s.s.) myrmicae Schonrogge } \\
\text { et al. }\end{array}$ & United Kingdom & {$[16]$} & 1 \\
\hline Pheidole dentata Mayr & Serichlamys rufipes (Macquart) & USA & {$[38]$} & 1 \\
\hline \multicolumn{5}{|l|}{ Unidentified ants } \\
\hline & $\begin{array}{l}\text { Archimicrodon (s.l.) brachycerus (Knab } \\
\text { and Malloch) }\end{array}$ & Australia & {$[65]$} & 1 \\
\hline & $\begin{array}{l}\text { Paramixogaster daveyi (Knab and } \\
\text { Malloch) }\end{array}$ & Australia & {$[65]$} & 1 \\
\hline & Paramixogaster vespiformis (Meijere) & Indonesia & Collection: ZMAN & 1 \\
\hline
\end{tabular}

*Reported as "Monomorium minutum (Buckley)" by Greene [37, 64]. The valid name fort that taxon is Monomorium monomorium Bolton, but that is an Old World species, whereas the records are from North America. Probably Greene erroneously mixed up the names minimum and minutum.

\section{Discussion}

4.1. Are All Microdontinae Associated with Ants? The larval habits remain unknown for the majority of microdontine taxa: 14 out of 43 genera are now known to be associated with ants. The present results, however, indicate that associations with ants are found well distributed over the tree representing the most recent phylogenetic hypothesis of Microdontinae (Figure 1). Spheginobaccha de Meijere (tribe Spheginobacchini) is the sister group to all other Microdontinae (tribe Microdontini), but the larvae of this taxon are presently unknown. Within the tribe Microdontini (the remaining part of the tree), Mixogaster Macquart is the first genus to branch off (a strongly supported clade; see Reemer and Ståhls [28]), 


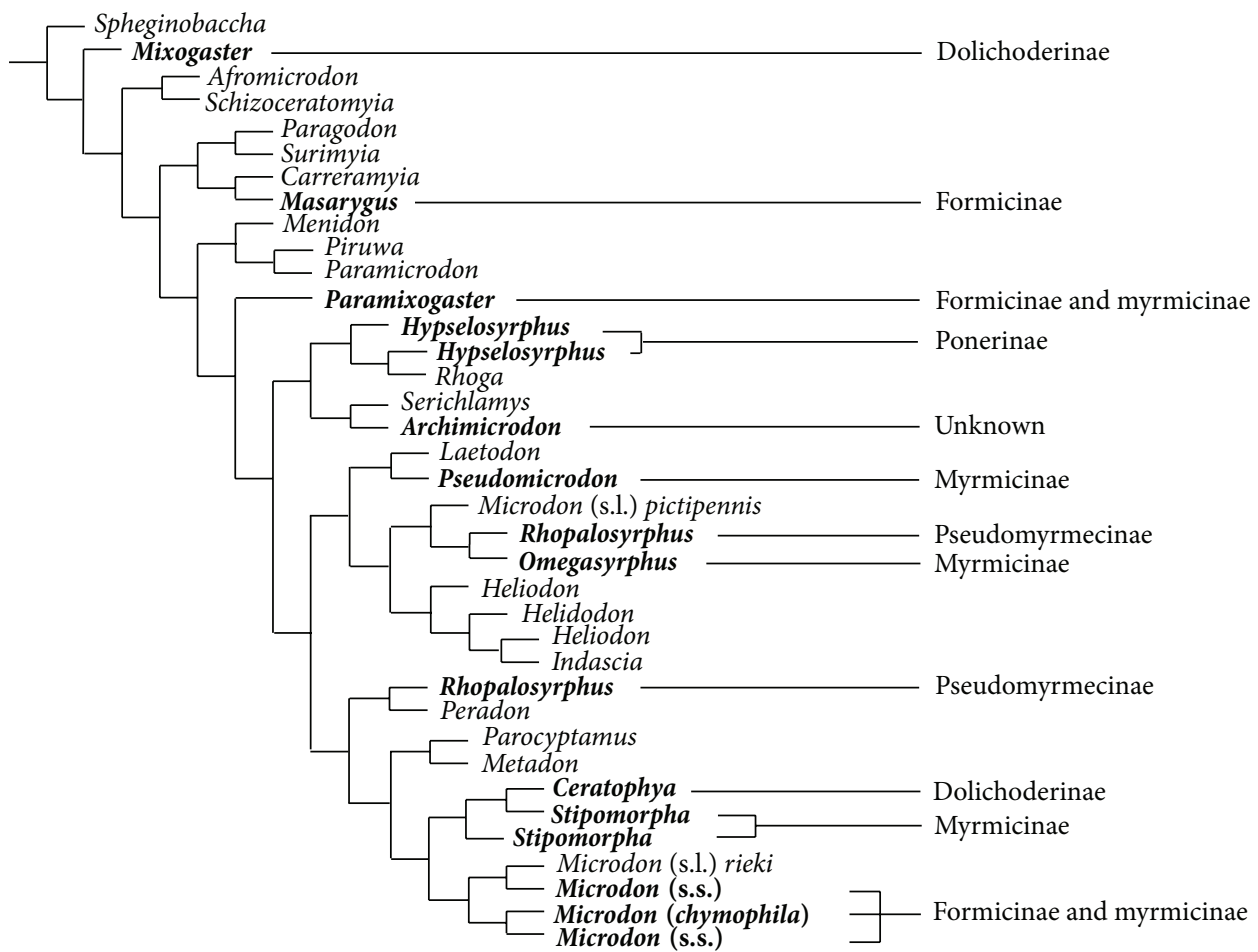

Figure 1: Phylogenetic hypothesis of 28 genera of Microdontinae (based on [28]), with indication of known associations with subfamilies of ants. Genera for which such associations are known are printed in bold. Note that several associations listed in Table 1 are lacking, because several taxa of Microdontinae were not included in the molecular dataset of [28].

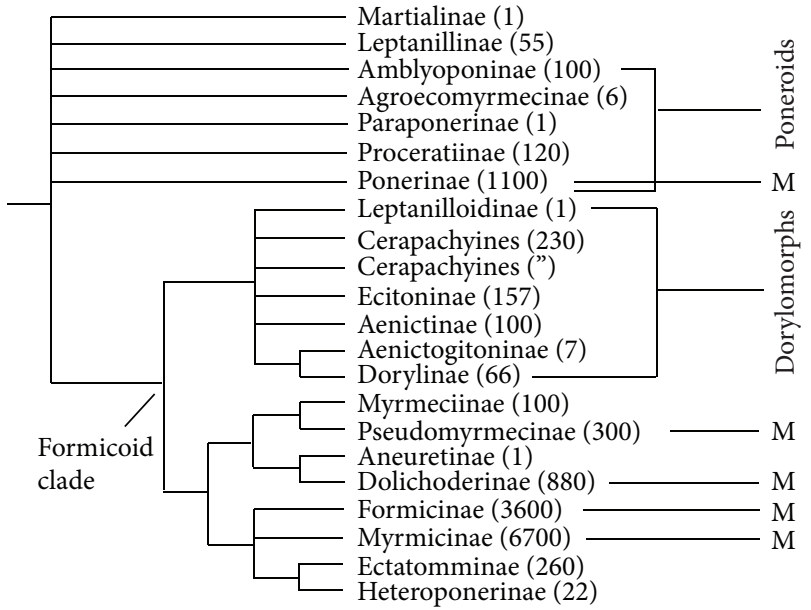

Figure 2: Phylogenetic tree summarizing well-supported relationships between extant subfamilies of ants (modified from [31]), with indication of known associations with Microdontinae ("M"). Numbers in parentheses are estimated numbers of described species per subfamily (based on [27, 31]).

and larvae of a species belonging to this genus have been found in an ant nest [35]. These results do not give a definite answer to the question, but they indicate that associations with ants are a dominant feature of larval biology for all Microdontinae, which has evolved early in the evolution of the group. Obviously, as already exclaimed by Cheng and
Thompson [66], "one wants to know what the larvae of Spheginobaccha do!”

4.2. Are Microdontinae Associated with All Ants? The ant genera which have been recorded in association with Microdontinae belong to five subfamilies: Ponerinae, Dolichoderinae, Pseudomyrmecinae, Myrmicinae, and Formicinae. The four latter subfamilies all belong to the "formicoid clade" (Figure 2), as defined by Ward [31].

So far, no species of Microdontinae are known to be associated with the dorylomorph ant subfamilies (Figure 2), which also belong to the formicoid clade. This group includes the army ants: four subfamilies which are characterized by a nomadic lifestyle and mass foraging. The lack of records of associations of Microdontinae with army ants is remarkable, as these ants are relatively well studied and are known to host extremely rich communities of myrmecophiles [1]. It is tempting to hypothesize that the nomadic behaviour of these ants somehow prevents Microdontinae from getting adapted to them. However, when species numbers of the ant subfamilies are taken into account (Figure 2), it is clear that making such a statement would be jumping to conclusions. Together, the five subfamilies known to be associated with Microdontinae contain more than 12,000 species of ants, which is more than $95 \%$ of the world's ant diversity. With so few records available, chances that microdontine larvae are found in assocation with other groups of ants are small. These chances are even smaller when the geographical bias of the records is taken into consideration: a large majority 
of the records originate from the Palaearctic and Nearctic regions, whereas the subfamilies outside of the formicoid clade are predominantly tropical.

\subsection{Are Certain Clades of Microdontinae Associated with Cer-} tain Clades of Ants? So far, only one record of a poneroid ant associated with Microdontinae (Hypselosyrphus Hull) is known. Whether this is an exception or the tip of an iceberg remains uncertain until more data on associations of tropical taxa become available.

Figure 1 indicates that associations with the ant subfamilies Formicinae and Myrmicinae occur on several parts of the microdontine tree, without any obvious pattern. Associations with both subfamilies are even found within the same genus. For instance, Microdon (s.s.) mutabilis is associated with ants of the genus Formica (Formicinae), whereas the closely related Microdon myrmicae, which until recently was not separated from M. mutabilis, is associated with Myrmica ants [16]. Larvae of different species of Paramixogaster Brunetti were also recorded in association with ants of Formicinae and Myrmicinae (Table 1). These records suggest that shifts in host association between Formicinae and Myrmicinae occur relatively frequently. Whether this is also true for other ant subfamilies, or for other genera of Microdontinae, cannot be deduced from the presently available data. For most other genera of Microdontinae only one association is known (Table 1). An exception is Stipomorpha Hull, of which the larvae of two species were found in Crematogaster Lund nests. Another exception is Oligeriops Hull, of which two species were found in nests of Iridomyrmex Mayr. Whether these records indicate some degree of parallel evolution remains an open question, at least until a larger number of associations is be known.

4.4. Associations with Other Insects? Wasmann [23, 25] reported having found Microdon larvae in the nests of wasps and termites. This record was repeated by other authors $[2,4]$ but has never since been confirmed. Wheeler [32] reported a finding of Microdon larvae in the chambers of termite nests, but those were abandoned by the termites and occupied by ants of the genus Camponotus Mayr. He wrote "These ants regularly take possession of the chambers adjacent to the tree trunk supporting the termitarium and permit the termites to inhabit the remainder of the structure." A similar explanation may be true for Wasmann's reports of Microdon larvae in wasps and termites nests.

Another, apparently independent, record of an association of Microdon with termites was mentioned by Séguy [67], who stated that the larvae of a Microdon species were attracted to exuding saps on certain fruit trees that were attacked by termites. However, the source of this record is unclear and no figures of the larvae are provided, so whether this report really concerns Microdon larvae remains doubtful.

Pendlebury [68] described Paramixogaster icariiformis Pendlebury and hypothesized that its larva lives in the nest of the wasp species that it mimics, without presenting any other evidence than their similarity in appearance.

So, there are no convincing records of Microdontinae living in the nests of other insects than ants. All published records suggesting such associations can be considered doubtful.

\section{Concluding Remarks}

With so few associations known among the total of 12,500 described ant species and 454 described species of Microdontinae, any conclusion about evolutionary trends claiming general validity would be premature. Despite this, the present paper is the first to demonstrate in a phylogenetic context that it seems likely that all Microdontinae are associated with ants. Vice versa, associations with Microdontinae are found among a large diversity of ant subfamilies, suggesting that all ants may be prone to "infestation" by Microdontinae. Exceptions may occur, such as the army ants, with which no associations are known so far.

At least as interesting as the questions discussed in this paper is the question as to the exact nature of the associations between Microdontinae and ants. Available evidence for a few Palaearctic and Nearctic species shows that these species are predators of immature stages of ants (see Introduction). The species for which this feeding mode is known all belong to Microdon s.s. (in the sense of Reemer and Ståhls [19]) and Omegasyrphus. Whether the larvae of other genera of Microdontinae also feed this way remains to be discovered.

\section{Acknowledgments}

The author would like to thank the following persons for sharing information or helping with studying the collections they are curating: Ben Brugge (ZMAN), Jean-Paul Lachaud, Mirian Nunes Morales (DZUP), Gabriela Pérez-Lachaud, Graham Rotheray (RSME), and Manuel Zumbado (INBio). André van Loon and Gunilla Ståhls are thanked for commenting on an earlier version of the paper. Jean-Paul Lachaud was very helpful with updating the taxonomy of the ant hosts.

\section{References}

[1] B. Hölldobler and E. O. Wilson, The Ants, Harvard University Press, Cambridge, UK, 1990.

[2] J. K. Donisthorpe, The Guests of British Ants, Their Habits and Life-Histories, George Routledge \& Sons, London, UK, 1927.

[3] J. C. Hartley, "A taxonomic account of the larvae of some British Syrphidae," Proceedings of the Zoological Society of London, vol. 136, no. 4, pp. 505-573, 1961.

[4] W. M. Wheeler, "Studies on myrmecophiles. III. Microdon," Journal of the New York Entomological Society, vol. 16, pp. 202213, 1908.

[5] E. O. Wilson, The Insect Societies, Harvard University Press, Cambridge, UK, 1971.

[6] B. Barr, "Feeding behaviour and mouthpart structure of larvae of Microdon eggeri and Microdon mutabilis (Diptera, Syrphidae)," Dipterists Digest, vol. 2, pp. 31-36, 1995.

[7] R. M. Duffield, "Biology of Microdon fuscipennis (Diptera: Syrphidae) with interpretations of the reproductive strategies of Microdon species found north of Mexico," Proceedings of the Entomological Society of Washington, vol. 83, no. 4, pp. 716-724, 1981. 
[8] W. B. Garnett, R. D. Akre, and G. Sehlke, "Cocoon mimicry and predation by myrmecophilous Diptera (Diptera: Syrphidae)," Florida Entomologist, vol. 68, no. 4, pp. 615-621, 1985.

[9] B. Hocking, "Insect associations with the swollen thorn acacias," Transactions of the Royal Entomological Society of London, vol. 122, no. 7, pp. 211-255, 1970.

[10] A. F. Van Pelt and S. A. Van Pelt, "Microdon (Diptera: Syrphidae) in nests of Monomorium (Hymenoptera: Formicidae) in Texas," Annals of the Entomological Society of America, vol. 65, no. 4, pp. 977-978, 1972.

[11] T. Borgmeier, "Beitrag zur Biologie der Feuerameise und ihrer Gäste (Solenopsis geminata saevissima Sm.)," Deutscher Verein für Wissenschaft und Kunst in São Paulo, vol. 3, no. 1, pp. 1-9, 1923.

[12] T. Borgmeier, "Syrphidenlarven in ameisennestern," Die Naturwissenschaften, vol. 40, no. 2, p. 36, 1953.

[13] M. H. Maneval, "Captures diverses au Mont Ventoux," Bulletin de la Société Entomologique de France, vol. 42, no. 1, pp. 66-67, 1937.

[14] R. W. Howard, R. D. Akre, and W. B. Garnett, "Chemical mimicry in an obligate predator of carpenter ants (Hymenoptera: Formicidae)," Annals of the Entomological Society of America, vol. 83, no. 3, pp. 607-616, 1990.

[15] R. W. Howard, D. W. Stanley-Samuelson, and R. D. Akre, "Biosynthesis and chemical mimicry of cuticular hydrocarbons from the obligate predator, Microdon albicomatus Novak (Diptera: Syrphidae) and its ant prey, Myrmica incompleta Provancher (Hymenoptera: Formicidae)," Journal of the Kansas Entomological Society, vol. 63, no. 3, pp. 437-443, 1990.

[16] K. Schönrogge, B. Barr, J. C. Wardlaw et al., "When rare species become endangered: cryptic speciation in myrmecophilous hoverflies," Biological Journal of the Linnean Society, vol. 75, no. 3, pp. 291-300, 2002.

[17] K. Schönrogge, M. G. Gardner, G. W. Elmes et al., "Host propagation permits extreme local adaptation in a social parasite of ants," Ecology Letters, vol. 9, no. 9, pp. 1032-1040, 2006.

[18] M. G. Gardner, K. Schönrogge, G. W. Elmes, and J. A. Thomas, "Increased genetic diversity as a defence against parasites is undermined by social parasites: Microdon mutabilis hoverflies infesting Formica lemani ant colonies," Proceedings of the Royal Society B, vol. 274, no. 1606, pp. 103-110, 2007.

[19] M. Reemer and G. Ståhls, "Generic revision and species classification of the Microdontinae (Diptera: Syrphidae)," ZooKeys, vol. 288, pp. 1-212, 2013.

[20] L. Lach, C. L. Parr, and K. L. Abbott, Eds., Ant Ecology, Oxford University Press, New York, NY, USA, 2010.

[21] U. Schmid, "Microdon rhenanus and Microdon eggeri var. major (Diptera, Syrphidae) revisited," Volucella, vol. 7, pp. 111-124, 2004.

[22] E. Wasmann, Zur Kenntniss der Ameisen und Ameisengäste von Luxemburg. III. Teil, Hofbuchdruckrei V. Bück, Luxemburg, 1909.

[23] E. Wasmann, "Vergleichende studien über ameisengäste und termitengäste," Tijdschrift voor Entomologie, vol. 33, no. 1, pp. 27-96, 1890.

[24] E. Wasmann, "Verzeichniss der ameisen und ameisengäste von holländisch limburg," Tijdschrift voor Entomologie, vol. 34, no. 1, pp. 39-64, 1890.

[25] E. Wasmann and E. Kritisches, Verzeichniss der Myrmekophilen und Termitophilen Arthropoden, Felix L. Dames, Berlin, Germany, 1894.
[26] N. A. Weber, "Two common ponerine ants of possible economic significance, Ectatomma tuberculatum (Olivier) and E. ruidum Roger," in Proceedings of the Entomological Society of Washington, vol. 48, no. 1, pp. 1-16, 1946.

[27] B. Bolton, "Synopsis and classification of formicidae," Memoirs of the American Entomological Institute, vol. 71, pp. 1-370, 2003.

[28] M. Reemer and G. Ståhls, "Phylogenetic relationships of Microdontinae (Diptera: Syrphidae) based on molecular and morphological characters," Systematic Entomology. In press.

[29] S. G. Brady, T. R. Schultz, B. L. Fisher, and P. S. Ward, "Evaluating alternative hypotheses for the early evolution and diversification of ants," Proceedings of the National Academy of Sciences of the United States of America, vol. 103, no. 48, pp. 18172-18177, 2006.

[30] C. S. Moreau, C. D. Bell, R. Vila, S. B. Archibald, and N. E. Pierce, "Phylogeny of the ants: diversification in the age of angiosperms," Science, vol. 312, no. 5770, pp. 101-104, 2006.

[31] P. S. Ward, “Taxonomy, phylogenetics, and evolution," in Ant Ecology, L. Lach, C. L. Parr, K. L. Abbott et al., Eds., pp. 3-17, Oxford University Press, New York, NY, USA, 2010.

[32] W. M. Wheeler, "Two extraordinary larval myrmecophiles from Panama," Proceedings of the National Academy of Sciences, vol. 10, no. 6, pp. 237-244, 1924.

[33] R. P. McMillan, "A contribution to the life history of a hover fly Microdon dimorphon Ferg., a dipterous inquiline," Western Australian Naturalist, vol. 5, no. 7, pp. 204-205, 1957.

[34] R. C. Shannon, "A new genus and five new species of Syrphidae from Australia (Diptera)," Proceedings of the Entomological Society of Washington, vol. 29, no. 4, pp. 82-87, 1927.

[35] M. Carrera and K. Lenko, "Descrição de duas espécies novas de Mixogaster (Diptera, Syrphidae) e observações sobre o inquilinismo de uma delas em ninhos de Iridomyrmex humilis, a 'formiga argentina,' Studia Entomologica, vol. 1, no. 3-4, pp. 465-486, 1958.

[36] A. Wild, Alex Wild Photography, 2012, http://www.alexanderwild.com/keyword/insects/1/1191657548_8rwSJ\#! $i=1292063955 \&$ $\mathrm{k}=\mathrm{bcGNtdn}$.

[37] C. T. Greene, "Larvae and pupae of the genera Microdon and Mixogaster (Diptera, Syrphidae)," Transactions of the American Entomological Society, vol. 81, no. 1, pp. 1-20, 1955.

[38] F. C. Thompson, "Revisionary notes on Nearctic Microdon flies (Diptera: Syrphidae)," Proceedings of the Entomological Society of Washington, vol. 83, no. 4, pp. 725-758, 1981.

[39] W. M. Mann, "Ant guests from Fiji and the British Solomon islands," Annals of the Entomological Society of America, vol. 13, no. 1, pp. 60-69, 1920.

[40] M. E. Schauff, "Microdonophagus, a new entedontine genus (Hymenoptera: Eulophidae) from Panama," Proceedings of the Entomological Society of Washington, vol. 88, no. 1, pp. 167-173, 1986.

[41] H. V. Weems, F. C. Thompson, G. E. Rotheray, and M. A. Deyrup, "The genus Rhopalosyrphus (Diptera: Syrphidae)," Florida Entomologist, vol. 86, no. 2, pp. 186-193, 2003.

[42] W. M. Wheeler, "Microdon larvae in Pseudomyrma nests," Psyche, vol. 9, no. 3, pp. 222-224, 1901.

[43] V. S. Schmid, M. N. Morales, L. Marinoni, R. Kamke, J. Steiner, and A. Zillikens, "Natural history and morphology of Microdon biluminiferus and its parasitic relationship with ants nesting in bromeliads," Journal of Insect Science. In press.

[44] R. D. Akre, W. B. Garnett, and R. S. Zack, "Ant hosts of Microdon (Diptera: Syrphidae) in the Pacific Northwest," Journal of the Kansas Entomological Society, vol. 63, no. 1, pp. 175-178, 1990. 
[45] R. D. Akre, W. B. Garnett, and R. S. Zack, "Biology and behaviour of Microdon piperi in the Pacific northwest (Diptera: Syrphidae)," Journal of the Kansas Entomological Society, vol. 61, no. 4, pp. 441-452, 1988.

[46] J. Brèthes, "Masarygidae. Una nueva familia de dípteros," Anales del Museo Nacional de Buenos Aires, vol. 10, 3rd series, pp. 439443, 1908.

[47] J. Longino, Camponotus (Dendromyrmex) nitidior (Santschi 1921), 2003, http://academic.evergreen.edu/projects/ants/genera/camponotus/species/nitidior/nitidior.html.

[48] T. Hironaga and M. Maruyama, "The myrmecophilous hoverfly genus Microdon (Diptera, Syrphidae, Microdontinae) in Hokkaidô, Japan, with descriptions of four new species," Bulletin of the National Science Museum, Tokyo A, vol. 30, no. 2, pp. 87-103, 2004.

[49] C. Hansson, J.-P. Lachaud, and G. Pérez-Lachaud, "Entedoninae wasps (Hymenoptera, Chalcidoidea, Eulophidae) associated with ants (Hymenoptera, Formicidae) in tropical America, with new species and notes on their biology," ZooKeys, vol. 134, pp. 65-82, 2011.

[50] F. R. Cole, "Notes on the early stages of the syrphid genus Microdon (Diptera)," Pomona College Journal of Entomology and Zoology, vol. 15, no. 1, pp. 19-20, 1923.

[51] T. D. A. Cockerell and H. Andrews, "Some Diptera (Microdon) from nests of ants," Proceedings of the United States National Museum, vol. 51, no. 2141, pp. 53-56, 1916.

[52] R. D. Akre, G. Alpert, and T. Alpert, "Life cycle and behaviour of Microdon cothurnatus in Washington (Diptera: Syrphidae)," Journal of the Kansas Entomological Society, vol. 46, no. 3, pp. 327-338, 1973.

[53] F. Knab, "On some North American species of Microdon (Diptera: Syrphidae)," Proceedings of the Biological Society of Washington, vol. 30, no. 1, p. 1, 1917.

[54] C. T. Greene, "The larva and pupa of Microdon megalogaster Snow (Diptera)," Proceedings of the Entomological Society of Washington, vol. 25, no. 4, pp. 140-141, 1923.

[55] A. Laboulbène, "Brief miscellaneous communications," Annales de la Société Entomologique de France (6th Series), vol. 2, pp. 96106, 1882.

[56] W. P. Mackay and E. Mackay, The Ants of New Mexico (Hymenoptera: Formicidae), Edwin Mellen Press, Lewiston, NY, USA, 2002.

[57] P. Speiser, "Über einige syrphiden und zwei für die deutsche fauna neue clythiiden," Jahrbucher des Nassauischen Vereins für Naturkunde, vol. 66, no. 1, pp. 117-146, 1913.

[58] M. Maruyama and T. Hironaga, "Microdon katsurai, a new species of myrmecophilous hoverfly (Diptera, Syrphidae) from Japan, associated with Polyrhachis lamellidens (Hymenoptera, Formicidae)," Bulletin of the National Science Museum, Tokyo A, vol. 30, no. 4, pp. 173-179, 2004.

[59] R. S. Camargo, L. C. Forti, R. T. Fujihara, A. A. Carlos, and C. A. O. Matos, "Nota sobre a biologia de Microdon tigrinus (Diptera: Syrphidae), parasito social de Acromyrmex coronatus (Hymenoptera: Formicidae)," Boletin de Sanidad Vegetal Plagas, vol. 34, no. 3, pp. 343-347, 2008.

[60] L. C. Forti, R. S. Camargo, S. S. Verza, A. P. P. Andrade, R. T. Fujihara, and J. F. S. Lopes, "Microdon tigrinus (Diptera, Syrphidae): populational fluctuations and specificity to the nest of Acromyrmex coronatus (Hymenoptera: Formicidae)," Sociobiology, vol. 50, no. 3, pp. 909-919, 2007.

[61] J. T. Longino, "The Crematogaster (Hymenoptera, Formicidae, Myrmicinae) of Costa Rica," Zootaxa, vol. 151, pp. 1-150, 2003.
[62] W. M. Mann, "A new Microdon from Panama," Psyche, vol. 35, no. 3, pp. 168-170, 1928.

[63] W. H. Clark and A. F. van Pelt, "Myrmecophiles in ant nests, Big Bend National Park, Texas," in Proceedings of the 49th Annual Meeting of the Idaho Academy of Science, Idaho Falls, Idaho, USA, April 2007.

[64] C. T. Greene, "A contribution to the biology of N.A. Diptera," Proceedings of the Entomological Society of Washington, vol. 25, no. 2, pp. 82-91, 1923.

[65] F. Knab and J. R. Malloch, "New Australian Diptera from ants' nests," Transactions of the Royal Society of South Australia, vol. 36, pp. 233-237, 1912.

[66] X.-Y. Cheng and F. C. Thompson, "A generic conspectus of the Microdontinae (Diptera: Syrphidae) with the description of two new genera from Africa and China," Zootaxa, vol. 1879, pp. 2148, 2008.

[67] E. Séguy, "La biologie des diptères," Encyclopédie Entomologique, vol. 26, pp. 1-609, 1950.

[68] H. M. Pendlebury, "Notes on some mimetic insects from the Malay Peninsula," Proceedings of the Entomological Society of London, vol. 1, no. 1, pp. 37-39, 1927. 

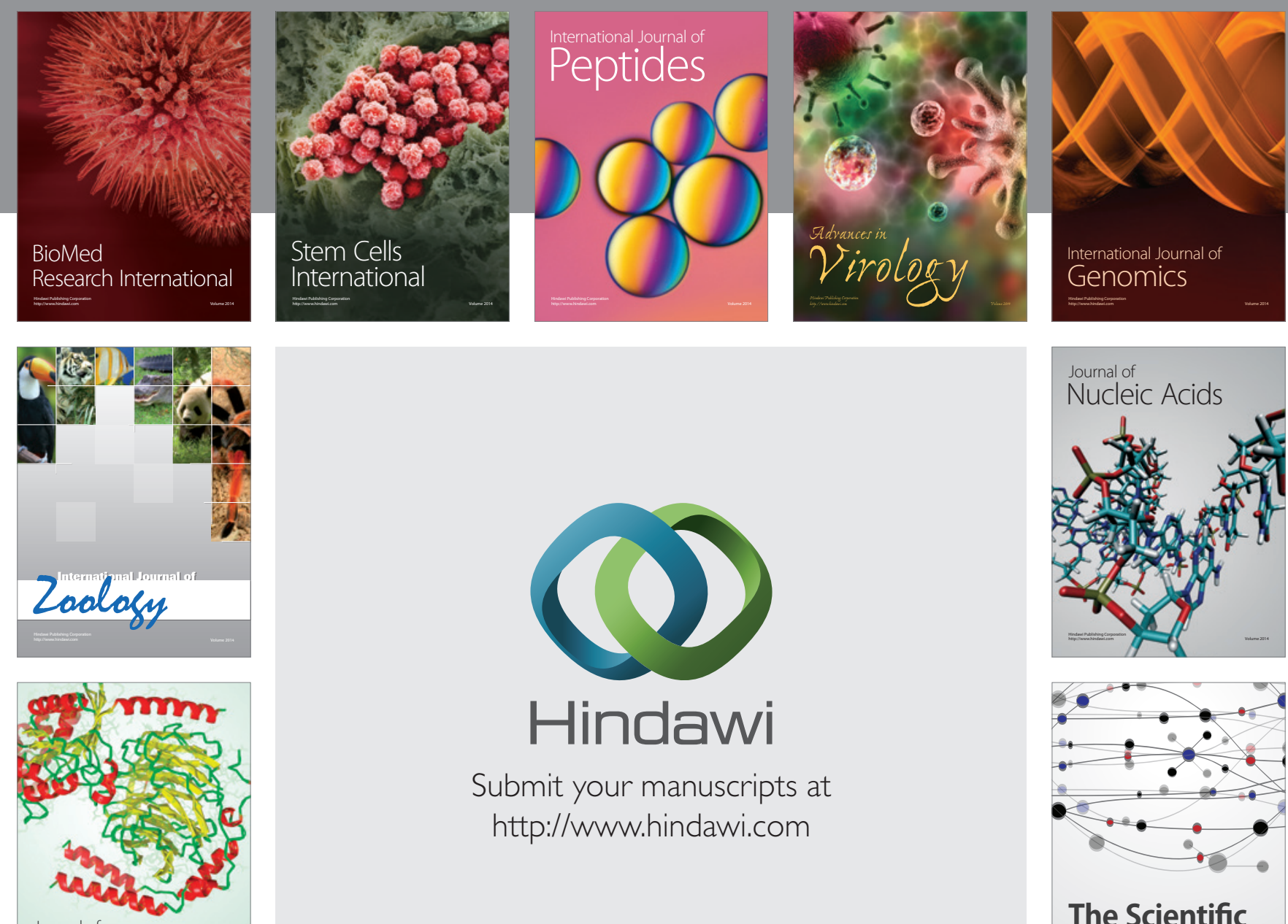

Submit your manuscripts at

http://www.hindawi.com

Journal of
Signal Transduction
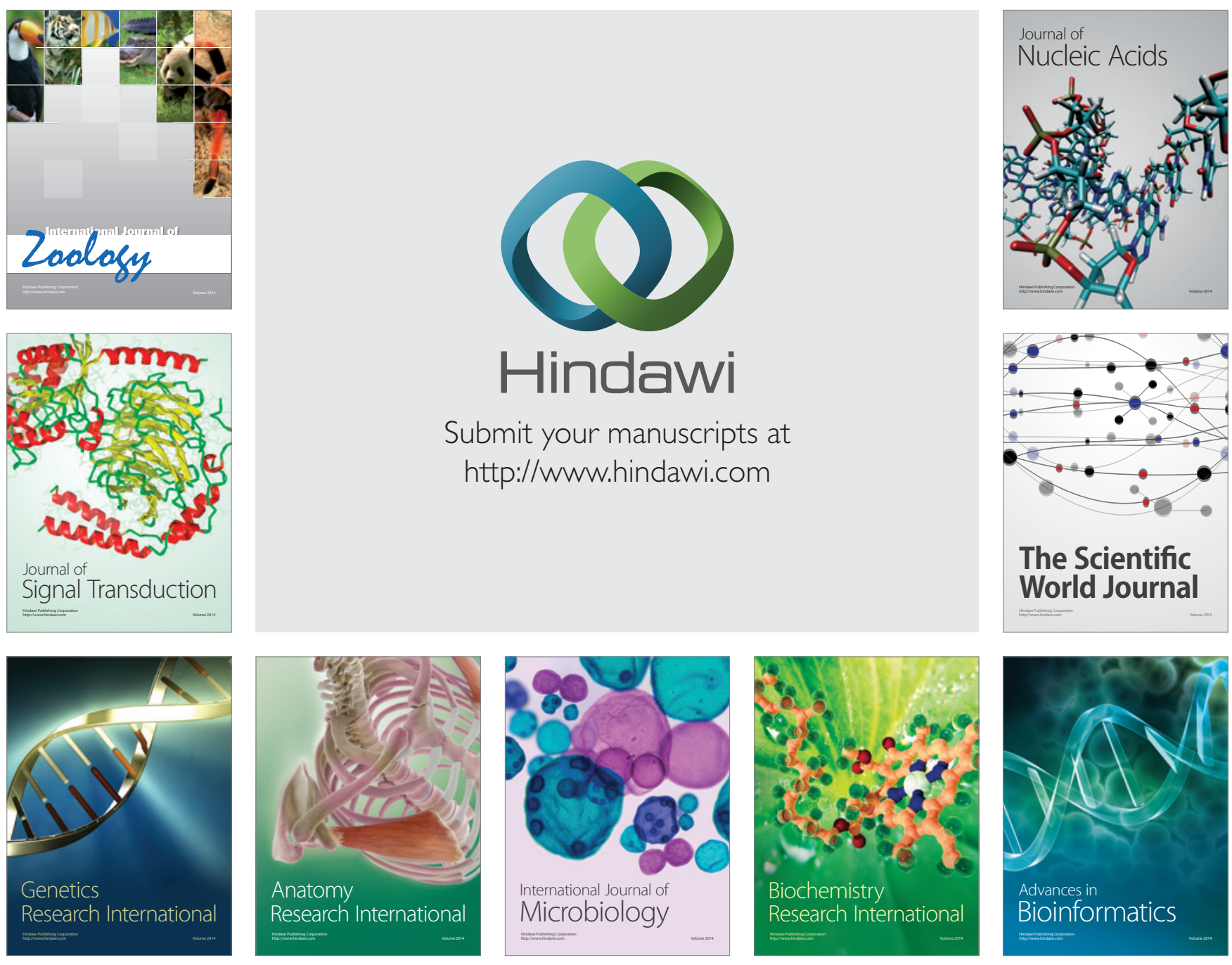

The Scientific World Journal
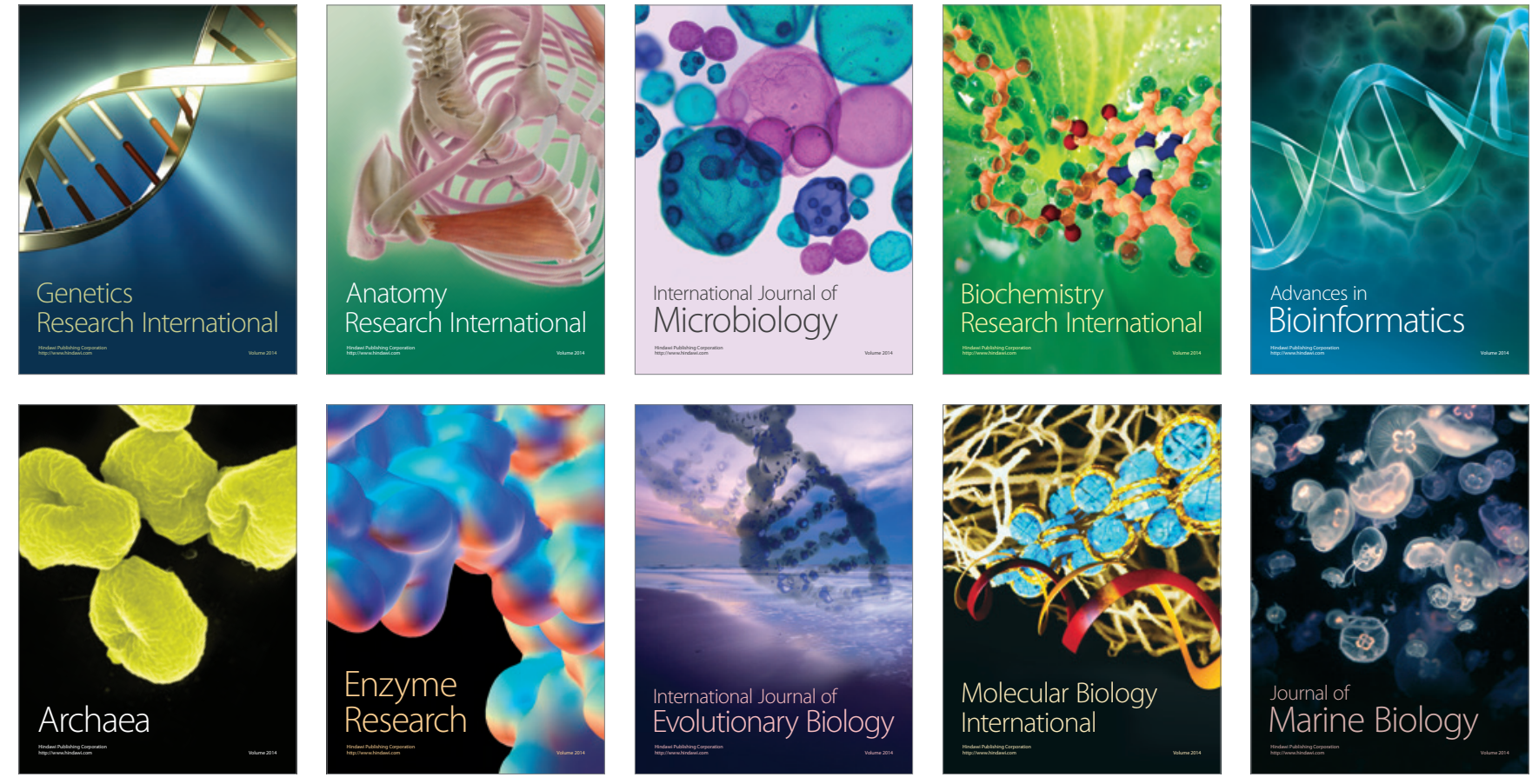